medRxiv preprint doi: https://doi.org/10.1101/2021.02.25.21252347; this version posted March 1, 2021. The copyright holder for this preprint

(which was not certified by peer review) is the author/funder, who has granted medRxiv a license to display the preprint in perpetuity.

It is made available under a CC-BY 4.0 International license .

\title{
Epidemiology and costs of post-sepsis morbidity, nursing care dependency, and mortality in Germany
}

\section{Authors:}

Dr. Carolin Fleischmann-Struzek ${ }^{1,2}$, Dr. Norman Rose ${ }^{1}$, Dr. Antje Freytag ${ }^{3}$, Dr. Melissa Spoden $^{4}$, Prof. Hallie C. Prescott ${ }^{5}$, Anna Schettler ${ }^{1,6}$, Lisa Wedekind ${ }^{7}$, Dr. Bianka Ditscheid ${ }^{3}$, Josephine Storch $^{3}$, Dr. Sebastian Born ${ }^{1,2}$, Prof. Peter Schlattmann ${ }^{1}$, Christian Günster ${ }^{4}$, Prof. Konrad Reinhart $^{8}$, Prof. Christiane S. Hartog ${ }^{8,9}$.

\section{Affiliations:}

1 Center for Sepsis Control and Care, Jena University Hospital/Friedrich Schiller University Jena, Jena, Germany

2 Institute of Infectious Diseases and Infection Control, Jena University Hospital, Jena, Germany

3 Institute of General Practice and Family Medicine, Jena University Hospital, Jena, Germany 4 Research Institute of the Local Health Care Funds (AOK), Berlin, Germany

5 Department of Medicine, University of Michigan, Ann Arbor, Michigan, US and VA Center for Clinical Management Research, Ann Arbor, Michigan, US

6 Department for Anesthesiology and Intensive Care Medicine, Jena University Hospital, Jena, Germany

7 Institute of Medical Statistics, Computer and Data Sciences, Jena University Hospital, Jena, Germany

8 Department of Anesthesiology and Operative Intensive Care Medicine, Charité Universitätsmedizin Berlin, Berlin, Germany

9 Klinik Bavaria, Kreischa, Germany

\section{Corresponding author:}


medRxiv preprint doi: https://doi.org/10.1101/2021.02.25.21252347; this version posted March 1, 2021. The copyright holder for this preprint

(which was not certified by peer review) is the author/funder, who has granted medRxiv a license to display the preprint in perpetuity. It is made available under a CC-BY 4.0 International license .

Dr. Carolin Fleischmann-Struzek

Center for Sepsis Control and Care

Institute of Infectious Diseases and Infection Control

Jena University Hospital

Stoystraße 3, 07743 Jena, Germany

Mail: carolin.fleischmann@med.uni-jena.de

Word count: 3316

Funding: German Innovations Fund of the Federal Joint Committee in Germany (G-BA) (grant number: 01VSF17010). The funder did not influence the design of the study, data collection, analysis and interpretation, as well as the writing of the manuscript.

This manuscript does not represent the views of the Department of Veterans Affairs or the US government. This material is the result of work supported with resources and use of facilities at the Ann Arbor VA Medical Center.

Conflicts of interest: The authors declare no competing interests.

Author contributions: CFS, NR, AF, MS, AS, LW, JS, SB, PS, CG, KR and CSH designed the study. AS and CFS developed the ICD-based definitions of postsepsis morbidity. AF, JS and $\mathrm{BD}$ are responsible for all issues concerning costs of care. MS, LW and JS prepared and checked the data. NR, MS, LW, JS and BD conducted the statistical analyses. CFS, NR, AF, MS, HCP, BD, KR and CSH interpreted the data. CFS and CSH wrote the first draft of the manuscript. All authors revised the manuscript for important intellectual content and approved the final manuscript.

Acknowledgements: We thank Prof. Frank Oehmichen, Dr. Wolfgang Sauter, Dr. Konrad Schmidt, Prof. Winfried Meißner, PD Dr. Christoph Preul, PD Dr. Jenny Rosendahl, Dr. 
medRxiv preprint doi: https://doi.org/10.1101/2021.02.25.21252347; this version posted March 1, 2021. The copyright holder for this preprint (which was not certified by peer review) is the author/funder, who has granted medRxiv a license to display the preprint in perpetuity. It is made available under a CC-BY 4.0 International license .

Romina Gawlytta and the SEPFROK expert panel (Prof. Horst Christian Vollmar, Prof. Uwe Janssens, Dr. Ruth Hecker, Arne Trumann, Dr. Simone Rosseau, Lothar Ullrich) for their contributions in the development of ICD-based definitions for postsepsis morbidity.

Data availability statement: The authors confirm that the data utilized in this study cannot be made available in the manuscript, the supplemental files, or in a public repository due to German data protection laws ('Bundesdatenschutzgesetz', BDSG). Therefore, they are stored on a secure drive in the AOK Research Institute (WIdO), to facilitate replication of the results. Generally, access to data of statutory health insurance funds for research purposes is possible only under the conditions defined in German Social Law (SGB V § 287). Requests for data access can be sent as a formal proposal specifying the recipient and purpose of the data transfer to the appropriate data protection agency. Access to the data used in this study can only be provided to external parties under the conditions of the cooperation contract of this research project and after written approval by the sickness fund. For assistance in obtaining access to the data, please contact wido@wido.bv.aok.de.

Take home message: This large population-based cohort of over 100,000 survivors of hospital-treated sepsis found high rates and a broad spectrum of new diagnoses consistent with post-sepsis morbidity, frequent new nursing care dependency, and high long-term mortality 1-3 years post sepsis. Post-sepsis morbidity was not limited to the oldest survivors or those with the most severe illness, but also affected younger survivors and those without pre-existing diagnoses. 
medRxiv preprint doi: https://doi.org/10.1101/2021.02.25.21252347; this version posted March 1, 2021. The copyright holder for this preprint (which was not certified by peer review) is the author/funder, who has granted medRxiv a license to display the preprint in perpetuity. It is made available under a CC-BY 4.0 International license.

\begin{abstract}
Purpose: To quantify the frequency and co-occurrence of new diagnoses consistent with post-sepsis morbidity, mortality, new nursing care dependency, and total healthcare costs after sepsis.
\end{abstract}

Methods: Population-based cohort study using healthcare claims data from 23 million beneficiaries of a German health insurance provider. We included adult patients with incident hospital-treated sepsis identified by ICD-10 codes in 2013-2014. New medical, psychological and cognitive diagnoses associated with post-sepsis morbidity; mortality; dependency on nursing care; and total health care costs in survivors were assessed to 3 years after hospital discharge.

Results: Among 116,507 sepsis patients who survived hospitalization for sepsis, $74.3 \%$ had a new medical, psychological or cognitive diagnosis in the first year after discharge. $20.6 \%$ and $3.8 \%$ had new diagnoses in two and three domains, respectively. $31.5 \%$ were newly dependent on nursing care, and $30.7 \%$ died within the first year. In the second and third year, $65.8 \%$ and $59.4 \%$ of survivors had new diagnoses, respectively. Healthcare costs totaled an average 36,585 Euro/patient in three years, including index hospitalization costs. Occurrence of new diagnoses in predefined subgroups was: $73.7 \%$ (survivors of non-severe sepsis), 75.6\% (severe sepsis), 78.3\% (ICU-treated sepsis), 72.8\% (non-ICU treated sepsis) and $68.5 \%$ (survivors without prior diagnoses).

Conclusions: New medical, psychological and cognitive diagnoses consistent with postsepsis morbidity are common after sepsis, including among patients with less severe sepsis, no prior diagnoses, and younger age. This calls for more efforts to elucidate the underlying mechanisms, define optimal screening for common new diagnoses, and test interventions to prevent and treat post-sepsis morbidity.

Trial Registration: DRKS00016340

Key words: sepsis, long-term, morbidity, mortality, survivors, population-based cohort 
medRxiv preprint doi: https://doi.org/10.1101/2021.02.25.21252347; this version posted March 1, 2021. The copyright holder for this preprint

(which was not certified by peer review) is the author/funder, who has granted medRxiv a license to display the preprint in perpetuity. It is made available under a CC-BY 4.0 International license.

\section{Introduction}

Sepsis is a life-changing and disability-inducing event, resulting in considerable financial burden for healthcare systems [1-3]. An estimated 38 million patients survive sepsis each year [4], many of whom experience persisting health problems [1, 5], including new or worsened physical [6], psychological [7, 8] and cognitive [6] impairments . Because of these sequelae, sepsis survivors are often unable to return to work, need ongoing nursing care, and experience increased risk of death [9].

However, while the long-term consequences of sepsis are increasingly recognized, there are limited epidemiologic data on the co-occurrence of sepsis sequelae and the rate of sequelae in younger patients or those with less severe sepsis. In a nationwide US cohort of older sepsis survivors, one-sixth experienced persistent physical disability or cognitive impairment and one-third died during the following year $[6,10]$. In ICU-treated sepsis survivors, there seems to be a considerable overlap with the "post-intensive care syndrome" (PICS) [11]. However, $50 \%$ of severe sepsis patients in the US [12] and two thirds of hospitalized sepsis patients in Germany [13] are not treated in an ICU. Data on the prevalence of sepsis sequelae in this patient group are lacking.

The present study used nationwide longitudinal claims data for one third of the German population to (i) quantify the frequency and co-occurrence of new medical, psychological, and cognitive diagnoses consistent with post-sepsis morbidity, (ii) compare the rate of mortality and new diagnoses by age groups, sepsis severity, ICU-treatment and pre-existing diseases and (iii) measure the cumulative costs of care. 
medRxiv preprint doi: https://doi.org/10.1101/2021.02.25.21252347; this version posted March 1, 2021. The copyright holder for this preprint

(which was not certified by peer review) is the author/funder, who has granted medRxiv a license to display the preprint in perpetuity. It is made available under a CC-BY 4.0 International license.

\section{Methods}

The study was pre-registered (DRKS00016340) and approved by the Jena University Hospital institutional review board (2019-1282-Daten).

Data source

We performed a population-based observational cohort study using health claims data from the health insurer AOK (Allgemeine Ortskrankenkasse) from the years 2009-2017. Health insurance is mandatory in Germany; residents select any insurer and enroll without restriction. $\mathrm{AOK}$ is the largest, nationwide health insurer covering around $30 \%$ of the German population [14].

Identification of sepsis patients

Patients $\geq 15$ years with an inpatient hospitalization for sepsis (discharged 1/1/2013 through 12/31/2014) were identified by explicit ICD-10-GM-codes for sepsis (Supplement 1). We stratified the sepsis severity according to the sepsis-1/2 definitions $[15,16]$ as: sepsis - all forms; severe sepsis or septic shock (R65.1, R57.2); and non-severe sepsis. Coding of sepsis in Germany is rigorously controlled by the Medical Service of the Health Funds (MDK): Coding of non-severe sepsis in Germany is restricted to cases with positive blood culture and $2+$ SIRS criteria or to cases with 4 SIRS criteria in case of negative blood cultures according to German coding regulations $[17,18]$. The first hospital admission with sepsis during 20132014 was defined as the index hospitalization. We excluded patients with a prior diagnosis of sepsis occurring in the 2 years preceding hospitalization. Pre-existing diagnoses and comorbidities were assessed in a period up to five years prior to hospitalization. Therefore, patients who were not continuously insured by AOK from 01/01/2009 through the three year follow-up period the index hospitalization (or until death) were excluded.

Characteristics of sepsis patients with index hospitalization

Patient demographics and clinical characteristics were assessed based on hospital discharge data, as well as a 12-month look-back in inpatient and outpatient claims. Study definitions are presented in Supplement 1. Prior nursing home residency and dependency on nursing care were determined based on graded care needs (which entitle patients to long-term care insurance benefits) [19].

Determining new diagnoses and costs 
medRxiv preprint doi: https://doi.org/10.1101/2021.02.25.21252347; this version posted March 1, 2021. The copyright holder for this preprint (which was not certified by peer review) is the author/funder, who has granted medRxiv a license to display the preprint in perpetuity. It is made available under a CC-BY 4.0 International license .

New diagnoses consistent with post-sepsis morbidity were measured during the 1-12, 13-24 and 25-36 months after index hospital discharge. Based on a comprehensive literature review on post-sepsis morbidity, we identified relevant diagnoses and their associated ICD-10-GM codes (Supplement 1). Experts from intensive care, internal medicine, neurology, psychiatry, family medicine and rehabilitation medicine reviewed and approved the list of diagnoses consistent with post-sepsis morbidity. Diagnoses were grouped into three domains (medical, psychological, and cognitive). The medical domain included: respiratory, cardiovascular, cerebrovascular, renal, hepatic, metabolic, urogenital and neuromuscular/musculoskeletal diagnoses, sensory disorders, anaemia, fatigue, decubitus ulcer, pain, multidrug-resistant infections, complications of the tracheostomy and impairments of nutrition. The psychological domain included depression, anxiety, PTSD, sleeping disorders and substance abuse. The cognitive domain included mild to severe cognitive impairment as a single diagnosis. Both primary and secondary hospital discharge diagnoses as well as outpatient diagnoses labeled as confirmed diagnoses by the treating physicians [20] were included. We also assessed the co-occurrence of medical, cognitive, and psychological diagnoses; nursing care dependency; and post-discharge mortality. Finally, we used ICD-10-GM codes and OPS (Operationen- und Prozedurenschlüssel) codes to assess long-term mechanical ventilation and dialysis among sepsis survivors (Supplement 1).

We determined the prevalence of each diagnosis after sepsis; diagnoses were considered present if a relevant ICD-10 code was reported during at least one hospitalization or outpatient visit. Diagnoses were considered new if there was no related ICD-10 code during the 12-month look-back in inpatient and outpatient claims data. Survivors who did not have the particular diagnosis during the preceding 12 months were considered "at-risk" for incident diagnoses. Thus, incidence of each diagnosis in the $1^{\text {st }}$ year post sepsis was measured in only those patients at-risk (ie, did not have the diagnosis in the year prior to sepsis). Likewise, incident diagnoses in the $2^{\text {nd }}$ and $3^{\text {rd }}$ year survivors were measured among patients without the diagnosis through the $1^{\text {st }}$ and $2^{\text {nd }}$ years, respectively

We also measured total health care costs, including costs for hospitalizations, outpatient consultations, medications, treatments (e.g., physical therapy, occupational therapy) and rehabilitation. In the German healthcare system, insured patients fulfilling certain requirements are entitled to treatment in a rehabilitation facility. There is no specific rehabilitation for sepsis. As data on outpatient diagnoses, cases, case-related therapies and corresponding costs in Germany are available on only a quarterly basis, data from quarters 1- 
medRxiv preprint doi: https://doi.org/10.1101/2021.02.25.21252347; this version posted March 1, 2021. The copyright holder for this preprint (which was not certified by peer review) is the author/funder, who has granted medRxiv a license to display the preprint in perpetuity. It is made available under a CC-BY 4.0 International license .

4, 5-8 and 9-12 following the quarter of the index hospitalization discharge date were included in the 12, 24 and 36 month follow-up, respectively.

Statistical Analyses

We reported continuous variables with means, standard deviations, medians and interquartile range (IQR) and categorical variables by proportions and 95\% confidence intervals (CIs). Chi-square test and Welch-Satterthwaite t-tests were used for comparisons between subgroups (e.g. severe vs. non-severe sepsis, ICU-treated vs. non-ICU-treated). For all descriptive and inferential statistical analyses, SAS Enterprise Guide 7.1 was used. Kaplan-Meier estimates of the survivor functions were used for survival analyses. Differences in the survivor functions between subpopulations over follow-up were tested with the log-rank test. To facilitate the interpretation of survivor functions, non-parametric estimates of the hazard functions based on B-splines with 95\% confidence bands are provided [21]. The software $\mathrm{R}$ was used for all survival analyses by means of the R packages 'survival' [22, 23] and 'bshazard'[24]. 
medRxiv preprint doi: https://doi.org/10.1101/2021.02.25.21252347; this version posted March 1, 2021. The copyright holder for this preprint (which was not certified by peer review) is the author/funder, who has granted medRxiv a license to display the preprint in perpetuity. It is made available under a CC-BY 4.0 International license .

\section{Results}

Among 23.0 million eligible individuals, there were 159,684 index sepsis hospitalizations during 2013-2014 (353/100,000 person-years, Figure 1A). Sepsis patients were a mean age of 73.8 years and had modest comorbidity burden (mean unweighted Charlson Comorbidity Index 2.1). $38.3 \%$ were dependent on nursing care prior to sepsis hospitalization, and $11.7 \%$ resided in nursing homes prior to sepsis hospitalization. Only 6.7\% had no pre-existing medical, psychological or cognitive diagnoses. $12.6 \%$ were employed prior to hospitalization.

Of 159,684 sepsis hospitalizations, 54,317 (34.0\%) received intensive care. 89,728 (56.2\%) had non-severe sepsis, while 69,956 (43.8\%) had severe sepsis, including 20,589 (29.4\%) with septic shock. Sepsis patients were hospitalized for a mean 20.6 days, and in-hospital mortality was $27.0 \%$ (Table 1). In-hospital mortality was higher in ICU-treated vs. non-ICUtreated patients $(40.6 \%$ vs $20.0 \%, \mathrm{p}<0.001)$, was higher for severe vs. non-severe sepsis (45.9\% vs. $12.3 \%, p<0.001)$, and highest in septic shock $(61.7 \%)$. Patients with no preexisting medical, psychological or cognitive diagnoses had an in-hospital mortality of $19.2 \%$. Overall, $5.5 \%$ of hospital survivors were discharged to inpatient rehabilitation. Detailed demographics and clinical features are reported in Supplement II Table S1.

Of the 116,507 patients who survived index hospitalization, $74.3 \%$ had a new medical, psychological, or cognitive diagnosis consistent with post-sepsis morbidity during their first year post-discharge (Figure 1B). Specifically, 70.9\% had a new medical diagnosis, $17.9 \%$ had a new psychological diagnosis, and $18.5 \%$ of patients had a new cognitive diagnosis (Table 2). Among 74,878 hospital survivors without prior nursing care dependency, $31.5 \%$ had new nursing care dependency during the first year post-sepsis. $1.6 \%$ and $2.8 \%$ of at-risk survivors required new long-term mechanical ventilation and renal replacement therapy, respectively.

The most common new diagnoses were neuromuscular/musculoskeletal, cardiovascular, respiratory, renal and urogenital diseases, occurring in $21 \%$ to $27 \%$ of at-risk survivors, respectively (Figure 2, Supplement II Table S2). New diagnoses of decubitus ulcers, chronic pain, and nutritional impairment occurred in 13-14\% of at-risk survivors. New fatigue occurred in $8.2 \%$, dysphagia in $6.9 \%$, depression in $11.7 \%$, anxiety in $3.3 \%$, and PTSD in $0.2 \%$. $12.0 \%$ had new multi-drug resistant infections. New diagnoses in two and three domains occurred in $20.6 \%$ and $3.8 \%$ of survivors, respectively (Figure 1B). $39.9 \%$ had prevalent (pre-existing and new) diagnoses in two and $17.0 \%$ in all three domains in the first year post-sepsis. 
medRxiv preprint doi: https://doi.org/10.1101/2021.02.25.21252347; this version posted March 1, 2021. The copyright holder for this preprint (which was not certified by peer review) is the author/funder, who has granted medRxiv a license to display the preprint in perpetuity. It is made available under a CC-BY 4.0 International license .

In the second and third year post-sepsis, new diagnoses occurred in $65.8 \%$ and $59.4 \%$ of oneand two-year survivors, respectively (Figure 3). While prevalence of cognitive diagnoses remained relatively stable, and prevalence of medical and psychological diagnoses increased, and the incidence of new diagnoses decreased across all domains among patients who survived over the one- and two-year period post-sepsis, respectively (Supplement II Table S3).

New-onset diagnoses were more common among survivors of severe vs. non-severe sepsis (75.6\% any new diagnosis, 72.8\% new medical, 19.0\% new psychological diagnosis, and $19.9 \%$ new cognitive), vs. $73.7 \%$ any new diagnosis, $70.0 \%$ new medical, $17.4 \%$ new psychological, and $17.8 \%$ new cognitive diagnosis), $\mathrm{p}<0.001$ for each comparison, Table 3 , Table 3A, Supplement II Table S4), and among ICU-treated vs. non-ICU treated sepsis (78.3\% any new diagnosis, $75.3 \%$ new medical, $21.4 \%$ new psychological disease, and 20.2\% new cognitive diagnosis vs. $72.8 \%$ any, $69.3 \%$ medical, $16.5 \%$ psychological and $17.8 \%$ cognitive), $\mathrm{p}<0.001$ for each comparison, Table 3, Supplemental II Tables S5). Among survivors with no prior diagnoses, $63.5 \%$ had a new medical diagnosis, $25.0 \%$ had a new psychological diagnosis, and $12.8 \%$ had a new cognitive diagnosis (Table 3A, Supplement II Table S6, Supplement II Figure S1). Among survivors $<40$ years, 56.1\% had at least one new diagnosis, and this proportion increased with greater age (Table 3B).

New nursing care was more common in survivors of severe vs. non-severe sepsis $(34.8 \% \mathrm{vs}$. $29.9 \%, \mathrm{p}<0.001)$, and in ICU-treated vs. non-ICU treated survivors $(36.8 \%$ vs. $29.1 \%$, $\mathrm{p}<0.001) .19 .3 \%$ of survivors without pre-existing diseases required new nursing care. Among at-risk survivors aged $>80$ years, $47.7 \%$ required new nursing care. Likewise, new diagnoses in multiple domains were more common in severe vs. non-severe sepsis $(22.0 \%$ vs. $19.9 \%$ with new diagnoses in two domains, $\mathrm{p}<0.001$, and $4.6 \%$ vs. $3.4 \%$ in three domains, $\mathrm{p}<0.001)$, and in ICU-treated vs. non-ICU treated sepsis (24.2 vs. 19.2 and 5.2 vs. 3.3, respectively, each $\mathrm{p}<.001)$.

Among the 116,507 survivors of hospitalization for sepsis, one-year post-discharge mortality was $30.7 \%$, and the majority of post-hospital deaths occurred within 100 days of hospital discharge (17.6\% of hospitalization survivors died during the following 100 days, Figure 4A). One-year post-discharge mortality was higher in patients with severe vs non-sepsis sepsis, in ICU-treated vs non-ICU-treated sepsis, in patients with vs without pre-existing diagnoses (Figure 4B) and in older vs. younger patients. After approximately 100-150 days postdischarge, risk of subsequent mortality was similar between patients with severe vs. non- 
medRxiv preprint doi: https://doi.org/10.1101/2021.02.25.21252347; this version posted March 1, 2021. The copyright holder for this preprint (which was not certified by peer review) is the author/funder, who has granted medRxiv a license to display the preprint in perpetuity. It is made available under a CC-BY 4.0 International license .

severe sepsis, and between ICU-treated vs. non-ICU-treated sepsis. However, mortality remained higher in older patients and patients with pre-existing diseases for the full 3 years of follow-up (Supplement II Figure S2a-e).

Among all sepsis survivors, mean health care costs were 14,891 Euro per patient in the first year and decreased to 11,503 Euro and 10,521 Euro in the second and third year, respectively (Table 2). For survivors of severe sepsis compared to survivors of non-severe sepsis, total health care costs were about 1,600 Euro higher in the first year $(\mathrm{p}<0.001)$. Similar differences were also seen in the following years (Supplement II Tab. S4). On average, the total costs for ICU-treated sepsis were about 4,400 Euro higher than for non-ICU-treated sepsis in the first year after sepsis $(\mathrm{p}<0.001)$. This difference was also seen - on a smaller extent - in the second and the third year (Supplement II Table S5).

Total health care costs from index hospitalization through the third year post-discharge were a mean of 36,585 Euro per patient (Supplement II Table S7). Total costs averaged 39,025 Euro for patients with severe sepsis, and 34,682 Euro for patients with non-severe sepsis. 
medRxiv preprint doi: https://doi.org/10.1101/2021.02.25.21252347; this version posted March 1, 2021. The copyright holder for this preprint (which was not certified by peer review) is the author/funder, who has granted medRxiv a license to display the preprint in perpetuity.

\section{Discussion}

In this large population-based cohort of over 100,000 survivors of hospital-treated sepsis with longitudinal follow-up to 3 years post-discharge, there were high rates of new diagnoses consistent with post-sepsis morbidity, new nursing care dependency, and death. Specifically, three-fourths of survivors were diagnosed with a new medical, psychological, or cognitive condition consistent with post-sepsis morbidity, and one-third died in the first year. Among survivors without pre-existing nursing care dependency, nearly one third were newly dependent on nursing care during the year following sepsis hospitalization. In the subsequent two years, more than half of survivors were diagnosed with a new condition, and one in six survivors died. New medical, psychological, and cognitive diagnoses co-occurred in a quarter of survivors. Importantly, and in contrast to many prior studies, this study captured a broad range of sepsis survivors, and showed that post-sepsis morbidity is not limited to the oldest survivors or those with the most severe illness-but also impacts younger survivors and those without pre-existing diagnoses.

With approximately 320,000 annual sepsis patients in Germany [13], the total direct costs for acute and three-year follow-up health care can be estimated at 11.7 billion Euro per year. The full economic impact of sepsis would be even higher if one considers reduced economic productivity of survivors, need for informal nursing care, and lifechanging effects on caregivers $[25,26]$, for whom many survivors depend on physical and financial support. These results highlight the considerable burden of sepsis and its long-lasting and multifaceted sequelae for patients, families, and the healthcare system.

The rate of new diagnoses consistent with post-sepsis morbidity in our cohort may be higher than prior estimates. In a longitudinal cohort of older Americans, sepsis survivors acquired a median 1-2 new functional limitations, and 10.6\% developed new moderate-severe cognitive impairment following sepsis [6]. This prior study suggested—based on the incidence of new functional and cognitive impairment - that sepsis was likely associated with substantial need for new nursing home placement and informal caregiving by family members, but was unable to measure these downstream impacts directly. By contrast, our study directly measured the incidence of new nursing care dependency and found that a third of at-risk sepsis survivors were newly dependent on nursing care, one-fifth had new cognitive diagnoses, and one-eight of at-risk survivors had a new diagnosis of depression.

Although the majority of survivors had new diagnoses consistent with post-sepsis morbidity, only $5.5 \%$ were discharged to rehabilitation facilities. Cardiovascular diseases were among 
medRxiv preprint doi: https://doi.org/10.1101/2021.02.25.21252347; this version posted March 1, 2021. The copyright holder for this preprint (which was not certified by peer review) is the author/funder, who has granted medRxiv a license to display the preprint in perpetuity. It is made available under a CC-BY 4.0 International license .

the most common new diagnoses, likely with important mediator of long-term mortality in sepsis survivors [27]. The incidence of new pain diagnosis (13\%) in our cohort is similar to a previous case-control study which found that $16 \%$ of ICU-treated sepsis and non-sepsis patients suffered from chronic pain at six months, but could detect no difference between the two groups [28]. Fatigue is a severely disabling symptom and an important determinant of quality of life for sepsis survivors [26]. Fatigue incidence in our study (8\%) was in a similar range as reported by hospital-treated COVID-19 survivors [29]. This underscores that fatigue may also be associated with activation of the immune system [30]. Long-term ventilation is comparatively rare $(1.6 \%)$ but nonetheless affects several thousand survivors yearly at enormous costs [31]. The incidence of anxiety $(3.3 \%)$ or PTSD $(0.2 \%)$ in our study was much lower than assessed among convenience samples of survivors from a sepsis self-help group (anxiety 60\% and PTSD 69\%) [32]. The difference can be explained because we assessed incident diseases in a population-based cohort. On the other hand, psychological diagnoses may be under-captured in our cohort, if physicians fail to provide a diagnosis for survivor symptoms [5].

Our study provides new insight into post-sepsis morbidity. We found that the majority of survivors are affected regardless of age, sepsis severity, ICU treatment, or pre-existing diseases. Furthermore, our findings demonstrate that new medical, psychological and cognitive diagnoses consistent with post-sepsis morbidity are also common among patients who fulfil the criteria of non-severe sepsis according to the old sepsis- $1 / 2$ criteria $[15,16]$.

These findings raise questions about the sensitivity of the new sepsis-3 definition in terms of the differentiation between patients with uncomplicated infections, which are less likely to cause major long-term morbidity, and patients with severe infections, formerly categorized as sepsis without organ dysfunction. SIRS criteria are no longer part of the current sepsis definition $[33,34]$, but the presence of at least two SIRS criteria in patients with proven or clinical suspected infection seems to identify an increased risk for major post-infection morbidity and hospital mortality.

Overall, our findings highlight the burden of post-sepsis morbidity and the need to develop and implement better systems to support survivors [35]. Our study has several strengths. First, to our knowledge, it is the first study to comprehensively investigate the epidemiology of post-sepsis morbidity across a population-based cohort of adult patients of all ages and with different severities of sepsis. The study used nationwide data of the largest healthcare insurance provider in Germany and covers approximately one-third of all German patients. 
medRxiv preprint doi: https://doi.org/10.1101/2021.02.25.21252347; this version posted March 1, 2021. The copyright holder for this preprint (which was not certified by peer review) is the author/funder, who has granted medRxiv a license to display the preprint in perpetuity. It is made available under a CC-BY 4.0 International license .

Second, our study had a rigorous process to identify the specific diagnoses and diagnostic codes consistent with post-sepsis morbidity, based on a multi-professional panel of experts who care for patients after sepsis.

Several limitations need to be acknowledged. First, the identification of both sepsis patients and their subsequent diagnoses are dependent on the quality of coding. We used explicit sepsis codes for case identification, which have better specificity and positive predictive value than other strategies [36], but may miss some patients who meet clinical criteria for sepsis $[12,36]$. Second, measuring post-sepsis morbidity based on diagnostic codes may result in misclassification. However, systematic screening of survivors for new medical, psychological, and cognitive diagnoses would not be feasible for such a large, populationbased cohort. In Germany, the plausibility of inpatient and outpatient coding is audited by the Medical Services of the Health Care Funds and the Association of Statutory Health Insurance Physicians, which helps ensure the accuracy of coded diagnoses and mitigate the risk of misclassification in this study. Still, poor awareness of sepsis sequelae among patients and physicians may result in underdiagnosis. Third, our study is observational and cannot establish causality of post-sepsis morbidity. However, prior matched studies suggest that sepsis is causally associated with subsequent morbidity [9], particularly functional limitations, cognitive impairment, and select medical conditions. Fourth, our approach only allowed us to identify only new-onset diagnoses but not accelerated progression of pre-existing diagnoses. Fifth, our data lacked costs of emergency service utilization, transport, therapeutic aid prescriptions, dental care, homecare prescription, and nursing care, so underestimates the total financial toll of sepsis. Finally, we also cannot rule out that differences may exist in comparison with the general German patient population, but prior studies have suggested only small differences between AOK and non-AOK beneficiaries in Germany [37].

\section{Conclusion}

In this large, population-based cohort of sepsis survivors with longitudinal follow-up to 3 years, we found that post-sepsis morbidity is common across all age groups and severities of sepsis. The financial toll of sepsis is substantial. This study underscores the need to raise awareness of post-sepsis morbidity, which is poorly known and understood by sepsis survivors, clinicians, and policy makers. Future research is needed to prevent, screen for, and treat post-sepsis morbidity. The development of comprehensive rehabilitation infrastructure also requires a better understanding of the mechanisms of long-term morbidity. finally, this 
medRxiv preprint doi: https://doi.org/10.1101/2021.02.25.21252347; this version posted March 1, 2021. The copyright holder for this preprint

(which was not certified by peer review) is the author/funder, who has granted medRxiv a license to display the preprint in perpetuity. It is made available under a CC-BY 4.0 International license.

study underpins the request of the World Health Assembly in its sepsis resolution, which asks member states to provide "access to relevant health care for survivors". 
medRxiv preprint doi: https://doi.org/10.1101/2021.02.25.21252347; this version posted March 1, 2021. The copyright holder for this preprint (which was not certified by peer review) is the author/funder, who has granted medRxiv a license to display the preprint in perpetuity.

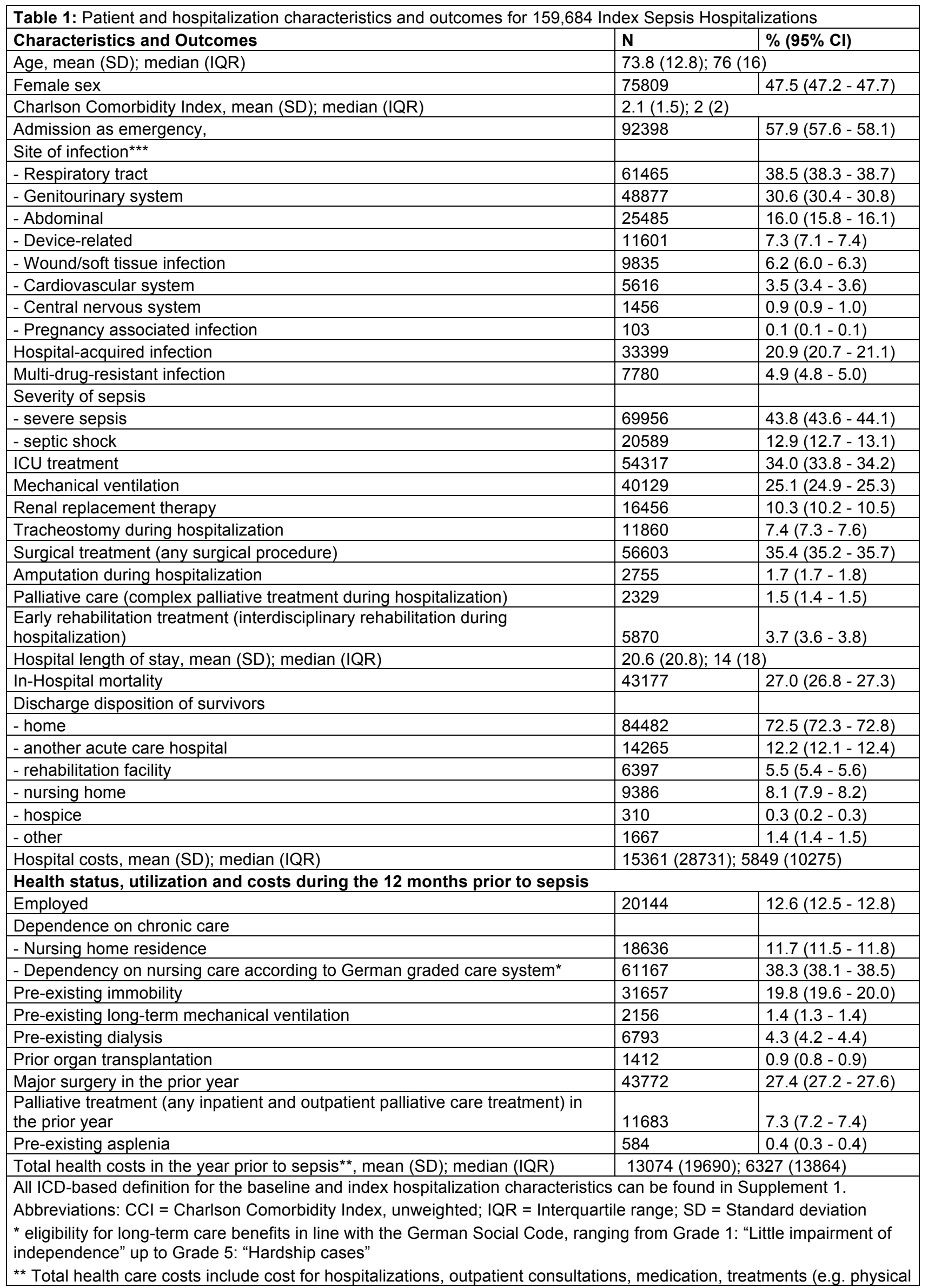


medRxiv preprint doi: https://doi.org/10.1101/2021.02.25.21252347; this version posted March 1, 2021. The copyright holder for this preprint (which was not certified by peer review) is the author/funder, who has granted medRxiv a license to display the preprint in perpetuity. It is made available under a CC-BY 4.0 International license .

or occupational therapy) and rehabilitation

*** Defined by ICD code indicating an infectious source, as indicated in methods supplement. Note that multiple sites of infection were possible. 


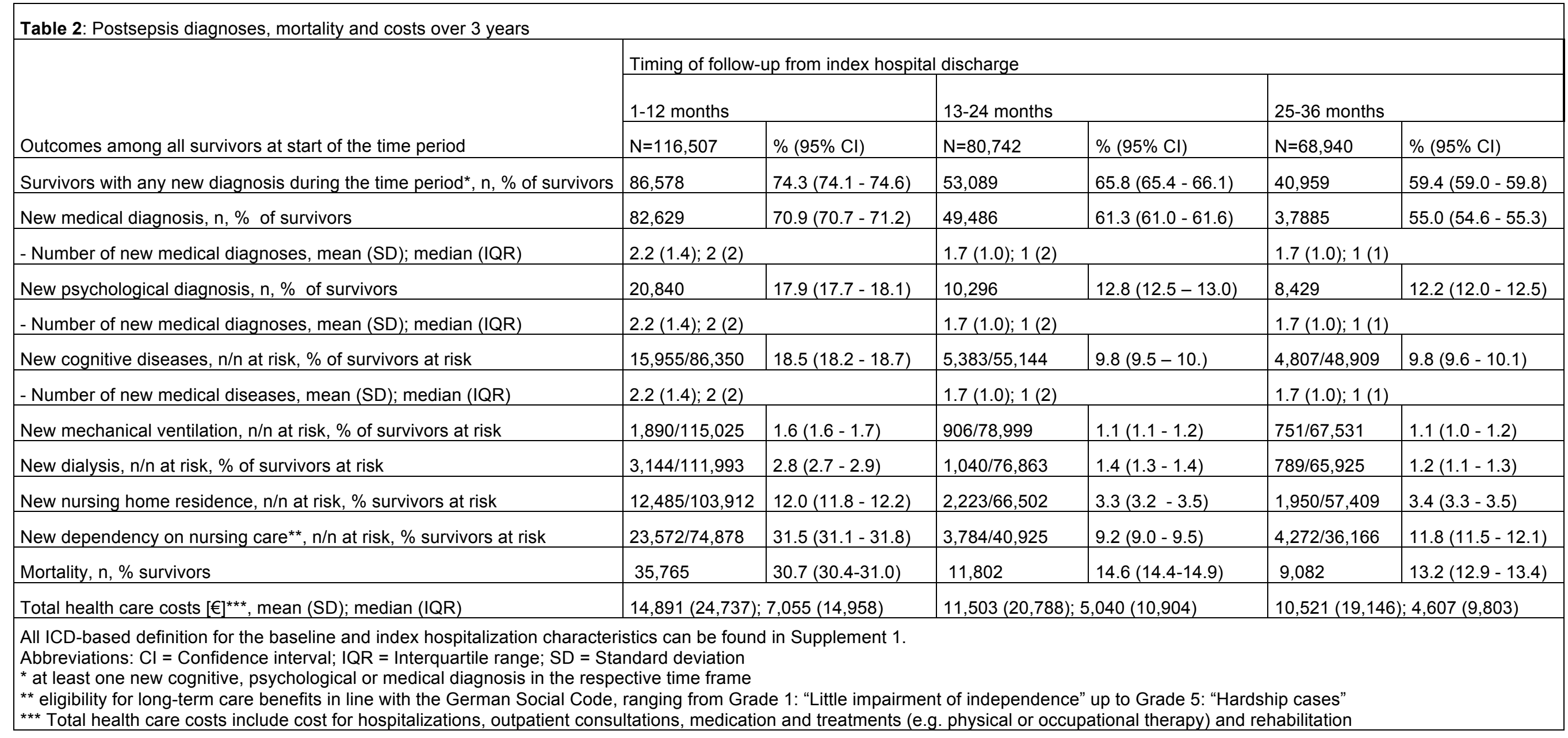




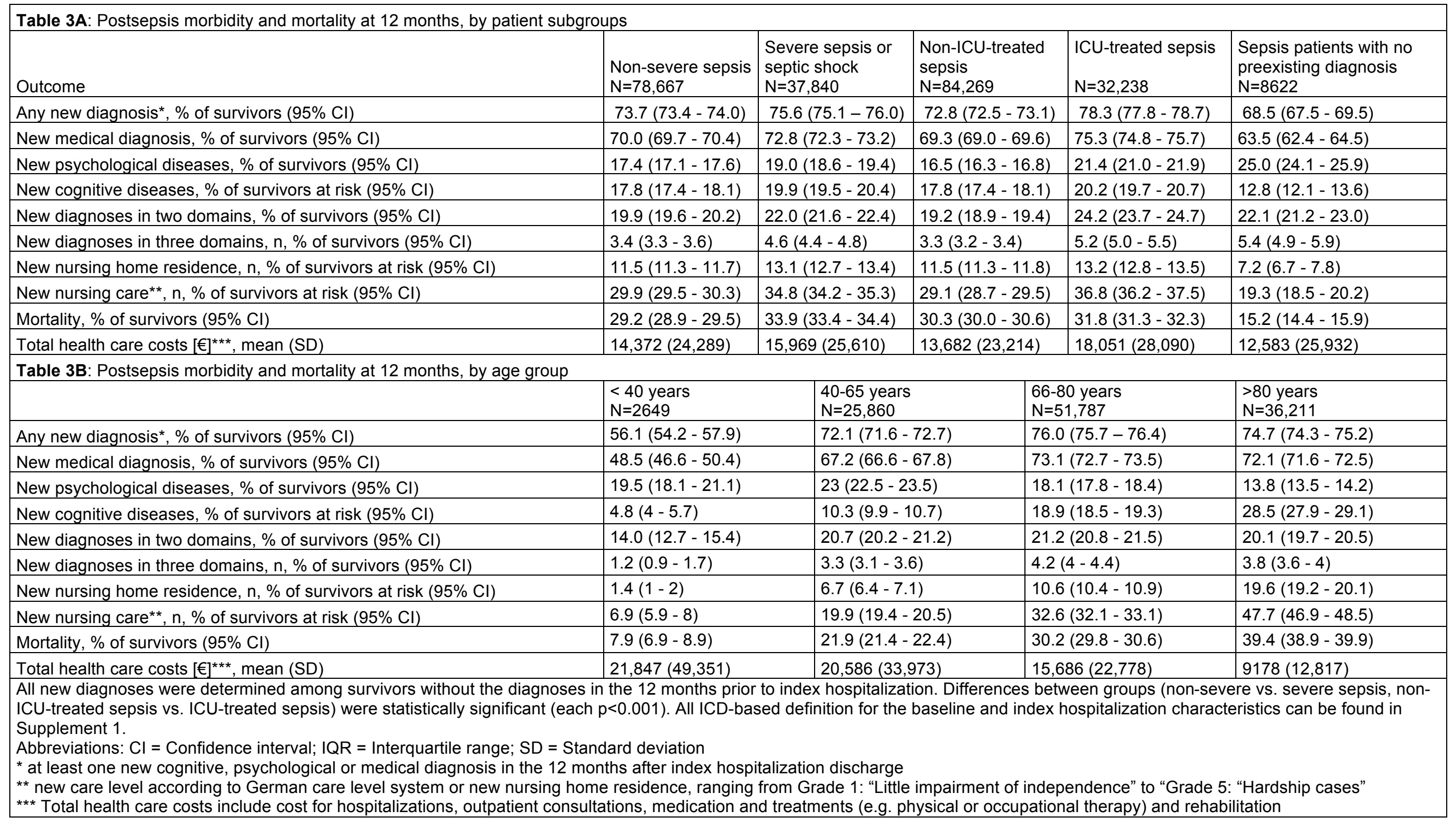


Figure 1: A) Flow of cohort, B) Postsepsis morbidity by domains and co-occurrence, in percent of survivors. This Euler Diagram shows the proportion of survivors with new medical, cognitive, or psychological diagnoses in the first year. $74.3 \%$ had a new diagnosis in at least 1 domain, $20.6 \%$ had new diagnoses in at least 2 domains, and $25.7 \%$ had no new diagnosis.

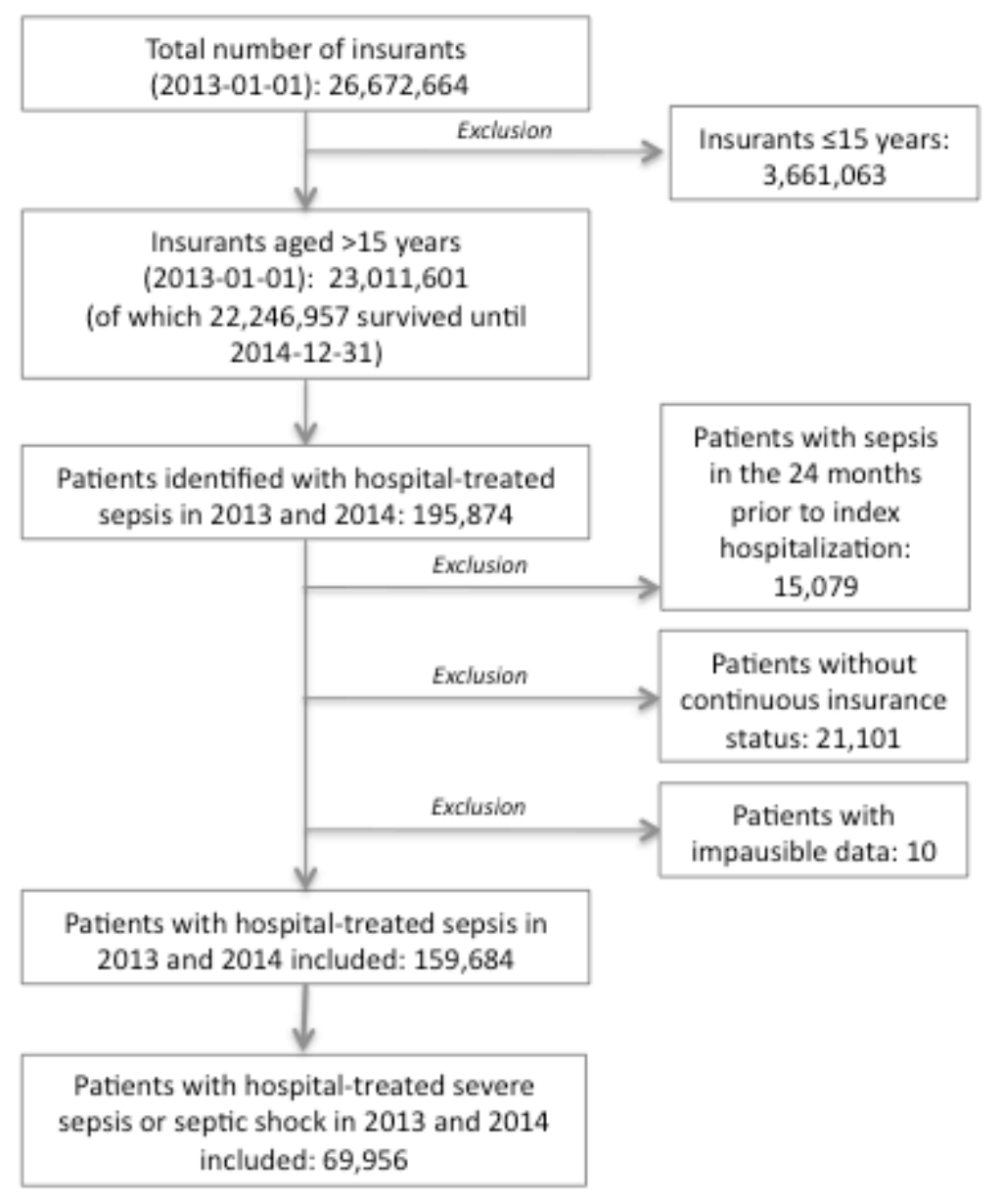

Survivors of hospital-treated sepsis in 2013 and 2014 ( $n=116,507)$ : New diagnoses 12 months postsepsis

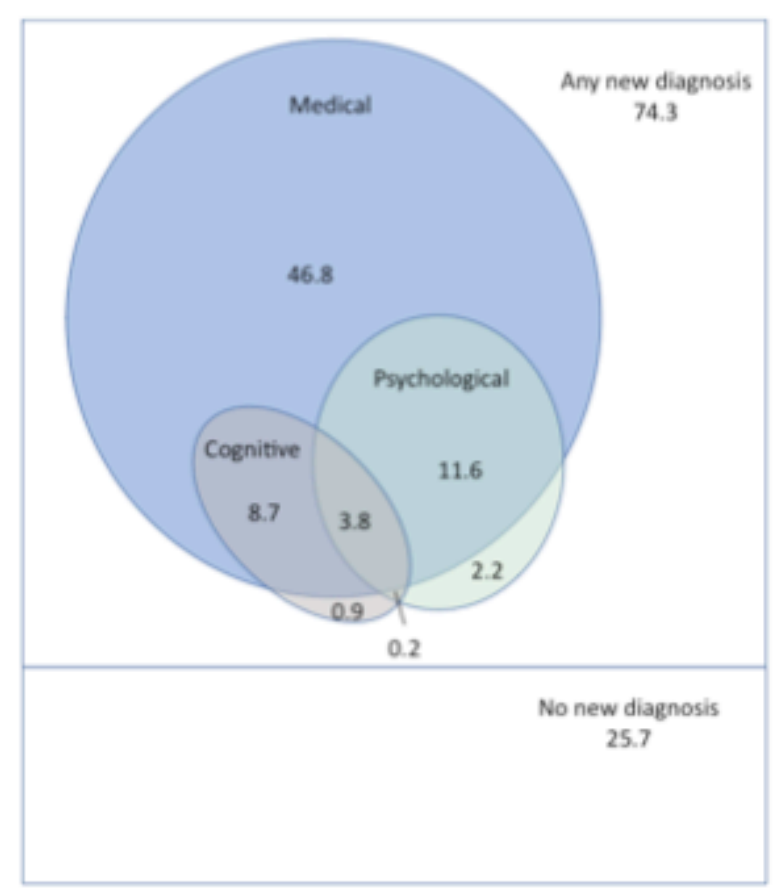


medRxiv preprint doi: https://doi.org/10.1101/2021.02.25.21252347; this version posted March 1, 2021. The copyright holder for this preprint (which was not certified by peer review) is the author/funder, who has granted medRxiv a license to display the preprint in perpetuity.

It is made available under a CC-BY 4.0 International license.

Figure 2: New postsepsis diagnoses in the 1-12 months after hospital discharge, in among survivors of non-severe vs. severe sepsis

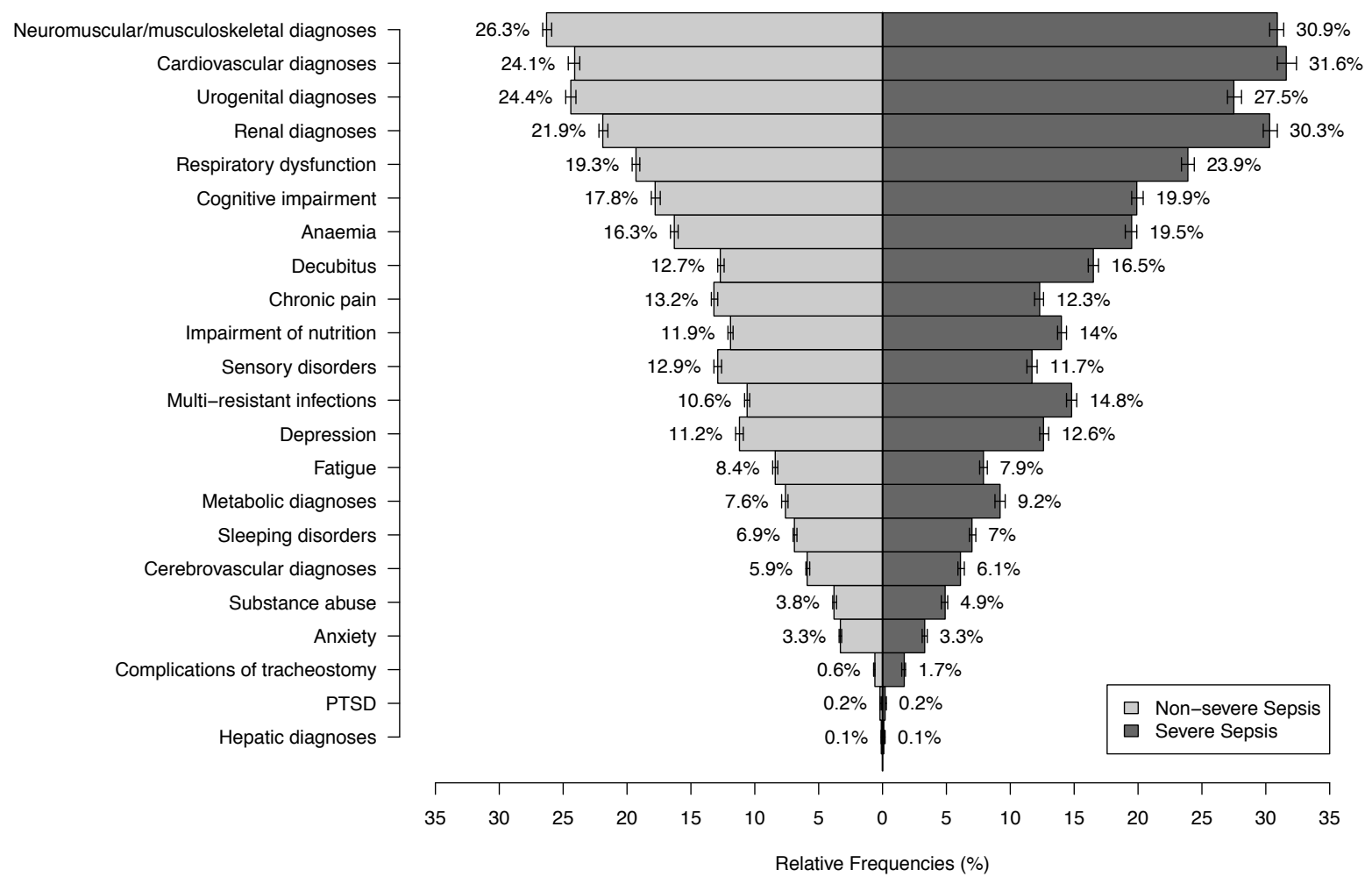


medRxiv preprint doi: https://doi.org/10.1101/2021.02.25.21252347; this version posted March 1, 2021. The copyright holder for this preprint (which was not certified by peer review) is the author/funder, who has granted medRxiv a license to display the preprint in perpetuity. It is made available under a CC-BY 4.0 International license .

Figure 3: Postsepsis morbidity and mortality 1-12, 13-24 and 25-36 months after sepsis

Post-sepsis Morbidity and Mortality
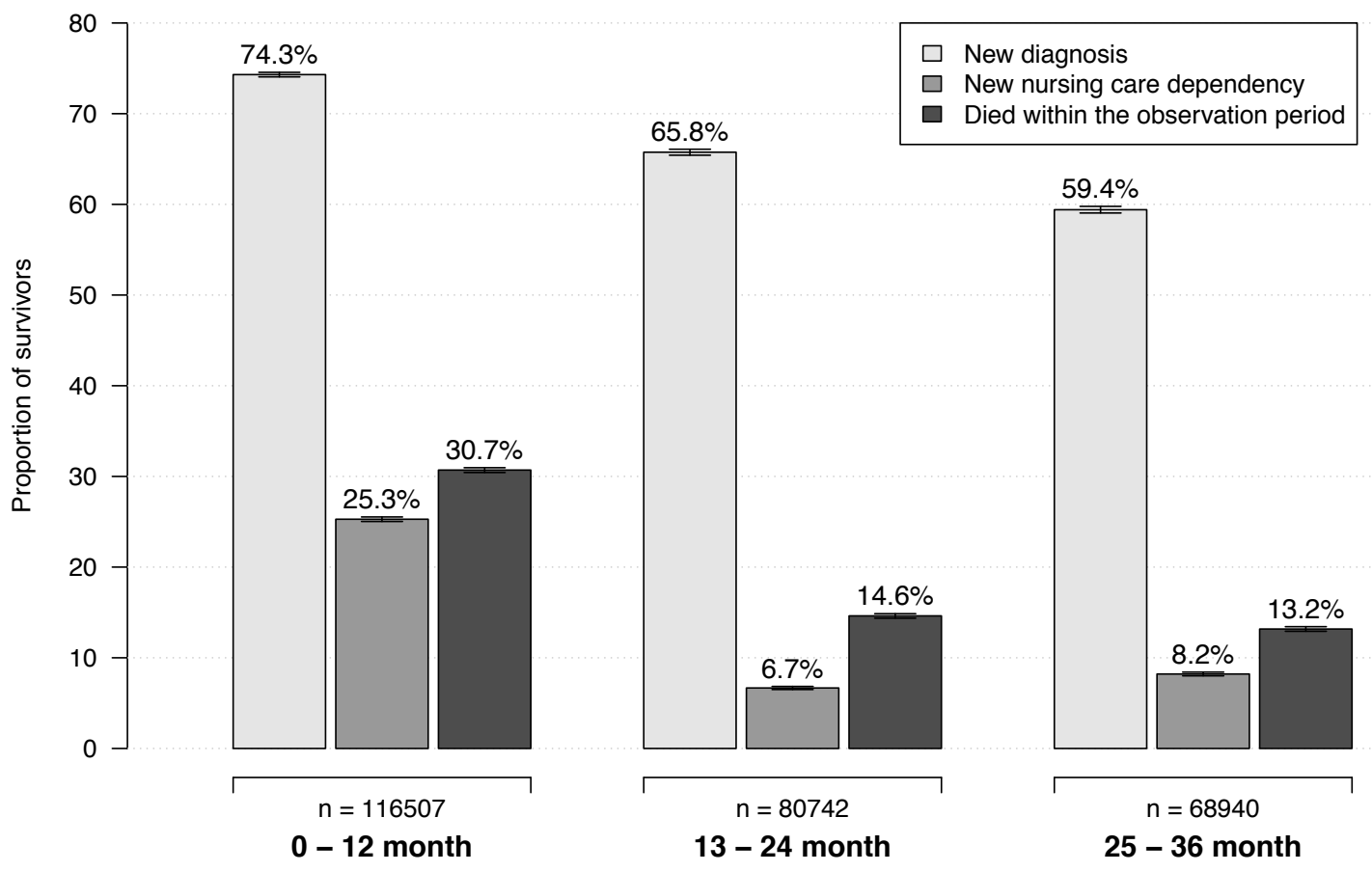

Legend This figure shows the percentage of afflicted survivors among all sepsis survivors in the first, second and third year after sepsis. Of note, the proportion of patients with new nursing need is related to all sepsis survivors in this figure 
medRxiv preprint doi: https://doi.org/10.1101/2021.02.25.21252347; this version posted March 1, 2021. The copyright holder for this preprint (which was not certified by peer review) is the author/funder, who has granted medRxiv a license to display the preprint in perpetuity. It is made available under a CC-BY 4.0 International license .

Figure 4: Kaplan-Meier Survival Curve of A) all sepsis patients, and B) sepsis patients according to pre-sepsis impairments, until 36 months after index hospital discharge. Survival analyses included all patients that survived the day of hospital discharge.

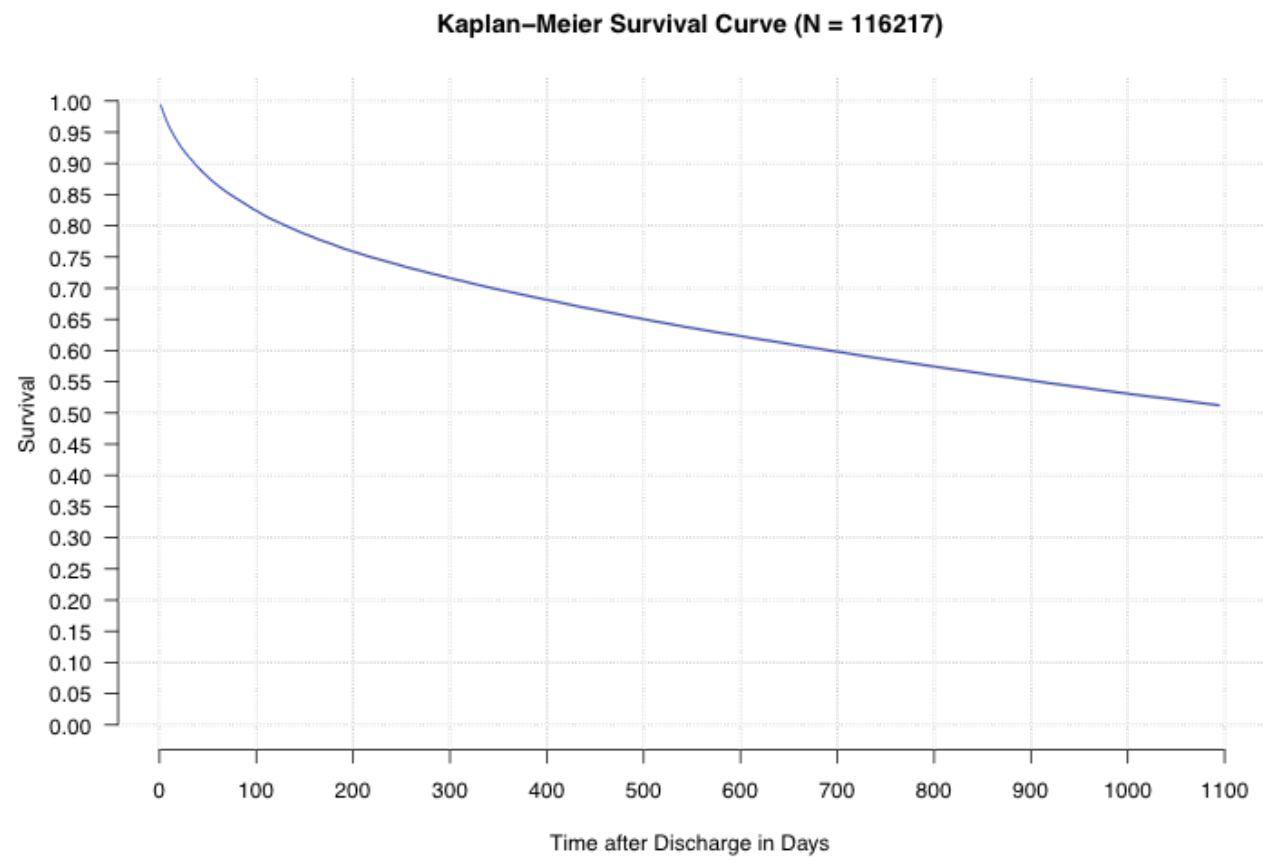

(A)

Kaplan-Meier Survival Curves by Pre-existing Diagnoses

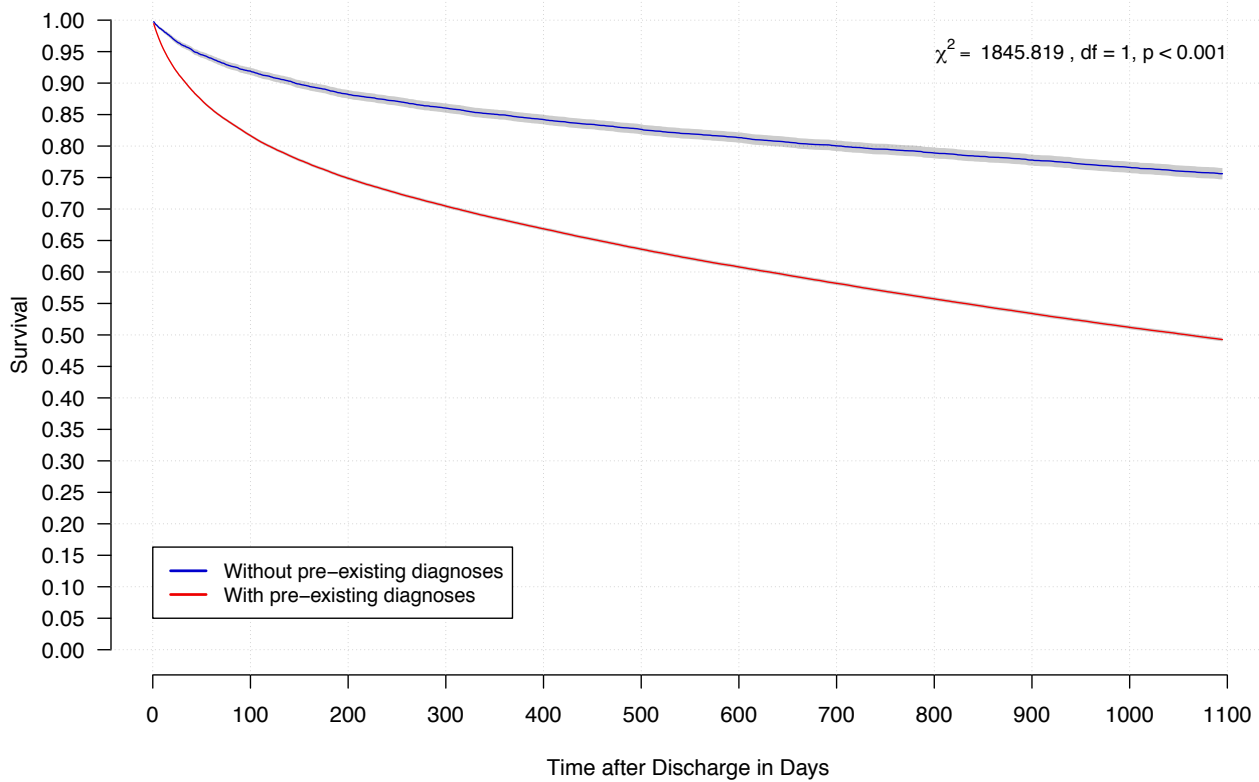

(B) 
medRxiv preprint doi: https://doi.org/10.1101/2021.02.25.21252347; this version posted March 1, 2021. The copyright holder for this preprint (which was not certified by peer review) is the author/funder, who has granted medRxiv a license to display the preprint in perpetuity. It is made available under a CC-BY 4.0 International license .

\section{References}

1. Prescott HC, Iwashyna TJ, Blackwood B, Calandra T, Chlan LL, Choong K, Connolly B, Dark P, Ferrucci L, Finfer S, Girard TD, Hodgson C, Hopkins RO, Hough CL, Jackson JC, Machado FR, Marshall JC, Misak C, Needham DM, Panigrahi P, Reinhart K, Yende S, Zafonte R, Rowan KM, Angus DC, (2019) Understanding and Enhancing Sepsis Survivorship. Priorities for Research and Practice. American journal of respiratory and critical care medicine 200: 972-981

2. Torio CM, Moore BJ (2016) National Inpatient Hospital Costs: The Most Expensive Conditions by Payer, 2013: Statistical Brief \#204Healthcare Cost and Utilization Project (HCUP) Statistical Briefs, Rockville (MD)

3. Buchman TG, Simpson SQ, Sciarretta KL, Finne KP, Sowers N, Collier M, Chavan S, Oke I, Pennini ME, Santhosh A, Wax M, Woodbury R, Chu S, Merkeley TG, Disbrow GL, Bright RA, MaCurdy TE, Kelman JA, (2020) Sepsis Among Medicare Beneficiaries: 1. The Burdens of Sepsis, 2012-2018. Critical care medicine 48: 276-288

4. Rudd KE, Johnson SC, Agesa KM, Shackelford KA, Tsoi D, Kievlan DR, Colombara DV, Ikuta KS, Kissoon N, Finfer S, Fleischmann-Struzek C, Machado FR, Reinhart KK, Rowan K, Seymour CW, Watson RS, West TE, Marinho F, Hay SI, Lozano R, Lopez AD, Angus DC, Murray CJL, Naghavi M, (2020) Global, regional, and national sepsis incidence and mortality, 1990-2017: analysis for the Global Burden of Disease Study. Lancet 395: 200-211

5. Huang CY, Daniels R, Lembo A, Hartog C, O'Brien J, Heymann T, Reinhart K, Nguyen HB, Sepsis Survivors Engagement P, (2019) Life after sepsis: an international survey of survivors to understand the post-sepsis syndrome. Int J Qual Health Care 31: 191-198

6. Iwashyna TJ, Ely EW, Smith DM, Langa KM, (2010) Long-term cognitive impairment and functional disability among survivors of severe sepsis. JAMA : the journal of the American Medical Association 304: 1787-1794

7. Rabiee A, Nikayin S, Hashem MD, Huang M, Dinglas VD, Bienvenu OJ, Turnbull AE, Needham DM, (2016) Depressive Symptoms After Critical Illness: A Systematic Review and Meta-Analysis. Critical care medicine 44: 1744-1753

8. Nikayin S, Rabiee A, Hashem MD, Huang M, Bienvenu OJ, Turnbull AE, Needham DM, (2016) Anxiety symptoms in survivors of critical illness: a systematic review and meta-analysis. Gen Hosp Psychiatry 43: 23-29

9. Prescott HC, Angus DC, (2018) Enhancing Recovery From Sepsis: A Review. JAMA : the journal of the American Medical Association 319: 62-75

10. Prescott HC, Langa KM, Liu V, Escobar GJ, Iwashyna TJ, (2014) Increased 1-year healthcare use in survivors of severe sepsis. American journal of respiratory and critical care medicine 190: 62-69

11. Needham DM, Davidson J, Cohen H, Hopkins RO, Weinert C, Wunsch $\mathrm{H}$, Zawistowski C, Bemis-Dougherty A, Berney SC, Bienvenu OJ, Brady SL, Brodsky MB, Denehy L, Elliott D, Flatley C, Harabin AL, Jones C, Louis D, Meltzer W, Muldoon SR, Palmer JB, Perme C, Robinson M, Schmidt DM, Scruth E, Spill GR, Storey CP, Render M, Votto J, Harvey MA, (2012) Improving long-term outcomes after discharge from intensive care unit: report from a stakeholders' conference. Critical care medicine 40: 502-509

12. Rhee C, Dantes R, Epstein L, Murphy DJ, Seymour CW, Iwashyna TJ, Kadri SS, Angus DC, Danner RL, Fiore AE, Jernigan JA, Martin GS, Septimus E, Warren DK, Karcz A, Chan C, Menchaca JT, Wang R, Gruber S, Klompas M, Program CDCPE, (2017) Incidence 
medRxiv preprint doi: https://doi.org/10.1101/2021.02.25.21252347; this version posted March 1, 2021. The copyright holder for this preprint (which was not certified by peer review) is the author/funder, who has granted medRxiv a license to display the preprint in perpetuity. It is made available under a CC-BY 4.0 International license.

and Trends of Sepsis in US Hospitals Using Clinical vs Claims Data, 2009-2014. JAMA : the journal of the American Medical Association 318: 1241-1249

13. Fleischmann-Struzek C, Mikolajetz A, Schwarzkopf D, Cohen J, Hartog C, Pletz M, Gastmeier P, Reinhart K, (2018) Challenges in Assessing the Burden of Sepsis and Understanding the Inequalities of Sepsis Outcomes between National Health Systems Secular Trends in Sepsis and Infection Incidence and Mortality in Germany Intensive care medicine 44: 1826-1835

14. Bundesministerium für Gesundheit (2015) Gesetzliche Krankenversicherung Mitglieder, mitversicherte Angehörige und Krankenstand 2014. In: Editor (ed)^(eds) Book Gesetzliche Krankenversicherung Mitglieder, mitversicherte Angehörige und Krankenstand 2014. City, pp.

15. Bone RC, Balk RA, Cerra FB, Dellinger RP, Fein AM, Knaus WA, Schein RM, Sibbald WJ, (1992) Definitions for sepsis and organ failure and guidelines for the use of innovative therapies in sepsis. The ACCP/SCCM Consensus Conference Committee.

American College of Chest Physicians/Society of Critical Care Medicine. Chest 101: 16441655

16. Levy MM, Fink MP, Marshall JC, Abraham E, Angus D, Cook D, Cohen J, Opal SM, Vincent JL, Ramsay G, (2003) 2001 SCCM/ESICM/ACCP/ATS/SIS International Sepsis Definitions Conference. Critical care medicine 31: 1250-1256

17. DIMDI (2007) Definition SIRS, Sepsis, schwere Sepsis und septischer Schock In: Editor (ed)^(eds) Book Definition SIRS, Sepsis, schwere Sepsis und septischer Schock City, pp.

18. Fleischmann-Struzek C, Mikolajetz A, Schwarzkopf D, Cohen J, Hartog CS, Pletz M, Gastmeier P, Reinhart K, (2018) Challenges in assessing the burden of sepsis and understanding the inequalities of sepsis outcomes between National Health Systems: secular trends in sepsis and infection incidence and mortality in Germany. Intensive care medicine 44: 1826-1835

19. Buscher A, Wingenfeld K, Schaeffer D, (2011) Determining eligibility for longterm care-lessons from Germany. Int J Integr Care 11: e019

20. KBV, (2011) Ambulante Kodierrichtlinien: Diagnosensicherheit und Seitenlokalisation. Dtsch Arztebl 108(6): A-271 / B-216 / C-216

21. Rebora P, Salim A, Reilly M B, (2014) A flexible tool for nonparametric smoothing of the hazard function. The R Journal 6: 114-22.

22. Therneau TM (2020) A Package for Survival Analysis in R. R package version 3.112. In: Editor (ed)^(eds) Book A Package for Survival Analysis in R. R package version 3.1-12., City, pp.

23. Therneau TM, Grambsch PM (2020) Modeling Survival Data: Extending the Cox Model. . Springer-Verlag New York

24. Rebora P, Salim A, Reilly M (2018) bshazard: Nonparametric Smoothing of the Hazard Function. . In: Editor (ed)^(eds) Book bshazard: Nonparametric Smoothing of the Hazard Function. . City, pp.

25. Cameron JI, Chu LM, Matte A, Tomlinson G, Chan L, Thomas C, Friedrich JO, Mehta S, Lamontagne F, Levasseur M, Ferguson ND, Adhikari NK, Rudkowski JC, Meggison H, Skrobik Y, Flannery J, Bayley M, Batt J, dos Santos C, Abbey SE, Tan A, Lo V, Mathur S, Parotto M, Morris D, Flockhart L, Fan E, Lee CM, Wilcox ME, Ayas N, Choong K, Fowler R, Scales DC, Sinuff T, Cuthbertson BH, Rose L, Robles P, Burns S, Cypel M, Singer L, Chaparro C, Chow CW, Keshavjee S, Brochard L, Hebert P, Slutsky AS, Marshall JC, Cook D, Herridge MS, Investigators RP, Canadian Critical Care Trials G, (2016) One-Year Outcomes in Caregivers of Critically Ill Patients. The New England journal of medicine 374: 1831-1841 
medRxiv preprint doi: https://doi.org/10.1101/2021.02.25.21252347; this version posted March 1, 2021. The copyright holder for this preprint (which was not certified by peer review) is the author/funder, who has granted medRxiv a license to display the preprint in perpetuity. It is made available under a CC-BY 4.0 International license .

26. Konig C, Matt B, Kortgen A, Turnbull AE, Hartog CS, (2019) What matters most to sepsis survivors: a qualitative analysis to identify specific health-related quality of life domains. Qual Life Res 28: 637-647

27. Ou SM, Chu H, Chao PW, Lee YJ, Kuo SC, Chen TJ, Tseng CM, Shih CJ, Chen YT, (2016) Long-Term Mortality and Major Adverse Cardiovascular Events in Sepsis Survivors. A Nationwide Population-based Study. American journal of respiratory and critical care medicine 194: 209-217

28. Baumbach P, Gotz T, Gunther A, Weiss T, Meissner W, (2016) Prevalence and Characteristics of Chronic Intensive Care-Related Pain: The Role of Severe Sepsis and Septic Shock. Crit Care Med 44: 1129-1137

29. Carfi A, Bernabei R, Landi F, Group ftGAC-P-ACS, (2020) Persistent Symptoms in Patients After Acute COVID-19. Jama

30. Lee C-H, Giuliani F, (2019) The Role of Inflammation in Depression and Fatigue. Front Immunol 10: 1696-1696

31. Karagiannidis C, Strassmann S, Callegari J, Kochanek M, Janssens U, Windisch W, (2019) [Evolving Epidemiology of Home Mechanical Ventilation: A Rapidly Growing Challenge for Patient Care]. Deutsche medizinische Wochenschrift 144: e58-e63 32. Rosendahl J, Brunkhorst FM, Jaenichen D, Strauss B, (2013) Physical and mental health in patients and spouses after intensive care of severe sepsis: a dyadic perspective on long-term sequelae testing the Actor-Partner Interdependence Model. Critical care medicine 41: 69-75

33. Kaukonen KM, Bailey M, Pilcher D, Cooper DJ, Bellomo R, (2015) Systemic inflammatory response syndrome criteria in defining severe sepsis. The New England journal of medicine 372: 1629-1638

34. Singer M, Deutschman CS, Seymour CW, Shankar-Hari M, Annane D, Bauer M, Bellomo R, Bernard GR, Chiche JD, Coopersmith CM, Hotchkiss RS, Levy MM, Marshall JC, Martin GS, Opal SM, Rubenfeld GD, van der Poll T, Vincent JL, Angus DC, (2016) The Third International Consensus Definitions for Sepsis and Septic Shock (Sepsis-3). JAMA : the journal of the American Medical Association 315: 801-810

35. Mostel Z, Perl A, Marck M, Mehdi SF, Lowell B, Bathija S, Santosh R, Pavlov VA, Chavan SS, Roth J, (2019) Post-sepsis syndrome - an evolving entity that afflicts survivors of sepsis. Mol Med 26: 6

36. Fleischmann-Struzek C, Thomas-Ruddel DO, Schettler A, Schwarzkopf D, Stacke A, Seymour CW, Haas C, Dennler U, Reinhart K, (2018) Comparing the validity of different ICD coding abstraction strategies for sepsis case identification in German claims data. PloS one 13: e0198847

37. Jeschke E, Gehrke T, Gunster C, Heller KD, Leicht H, Malzahn J, Niethard FU, Schrader P, Zacher J, Halder AM, (2019) Low Hospital Volume Increases Revision Rate and Mortality Following Revision Total Hip Arthroplasty: An Analysis of 17,773 Cases. J Arthroplasty 34: 2045-2050 